\title{
INFLUENCE OF THE METEOROLOGICAL CONDITIONS ON FOREST FIRES OCCURRENCES IN LICHINGA DISTRICT, NORTHERN MOZAMBIQUE
}

\author{
Aires Afonso Mbanze ${ }^{1 *}$, Antonio Carlos Batista ${ }^{2}$, Alexandre França Tetto ${ }^{2}$, Henrique Soares Koehler ${ }^{3}$, \\ Jose Bernardo Manteiga ${ }^{4}$ \\ ${ }^{1 *}$ Lúrio University, Faculty of Agricultural Sciences, Sanga, Niassa, Mozambique - aires.banze@ gmail.com \\ ${ }^{2}$ Federal University of Paraná, Department of Forest Sciences, Curitiba, Parana, Brazil - batistaufpr@ufpr.br; tetto@ufpr.br \\ ${ }^{3}$ Federal University of Paraná, Department of Plant Science and Fitossanitarismo, Curitiba, Paraná, Brazil - koehler@ufpr.br \\ ${ }^{4}$ Forests of Niassa, Lichinga, Niassa, Mozambique - manteigax95@ gmail.com
}

Recebido para publicação: 09/10/2013 - Aceito para publicação: 09/03/2015

\begin{abstract}
The aim of this study was to assess the influence of meteorological conditions on the fire occurrences in forest stands of Lichinga district, in the period from 2010 to 2012. Data about fire occurrences records of the district of Lichinga and two others close districts (Lago and Sanga) were provided by the Center for Monitoring and Control of Forest Fires (CCMIF) of the company Chikweti. Daily weather data: temperature, rainfall and relative humidity of the same period, recorded at 13:00 PM, by the meteorological station of the Institute of Agronomic Research of Mozambique (IIAM) in Lichinga district were also provided to this work. Meteorological data were submitted to regression analysis and Tukey test. The results showed a significant variation in temperature and humidity on both tests. The overlapping of fire occurrences and meteorological variables, suggested a great influence of the meteorological conditions in the occurrence of fires, mainly due to the very long dry periods. In 2010 there was a delay in the occurrence of fires; this was related to the rainy season which was slightly longer. September and October was the months that recorded the highest number of fire occurrences throughout the studied period.

Keywords: Forest stands; meteorological variable; forest fire prevention.
\end{abstract}

\section{Resumo}

Influência das condições meteorológicas na ocorrência dos incêndios florestais no distrito de Lichinga, norte de Moçambique. O objetivo deste estudo foi avaliar a influência das variáveis meteorológicas na ocorrência de incêndios em povoamentos florestais no distrito de Lichinga, no período de 2010 a 2012. Para tal, foram analisados os registros de ocorrências de incêndios do distrito de Lichinga e de outros dois distritos vizinhos (Lago e Sanga), disponibilizados pelo Centro de Controle e Monitoramento de Incêndios Florestais (CCMIF) da empresa Chikweti Forest of Niassa, e dados meteorológicos diários de temperatura (máxima e mínima), precipitação e umidade relativa, do mesmo período, registrados às 13 horas, pela estação meteorológica do Instituto de Investigação Agronômica de Moçambique em Lichinga (IIAM-Lichinga). Os dados meteorológicos foram submetidos ao teste de análise de regressão e ao teste de Tukey, tendo sido observado uma variação significativa da temperatura e umidade em ambos os testes. A sobreposição das ocorrências dos incêndios com as variáveis meteorológicas demostrou uma grande influênca dessas variáveis na ocorrência dos incêndios, principalmente devido aos períodos secos prolongados. No ano 2010 observou-se um atraso na ocorrência dos incêndios, devido ao período chuvoso que foi ligeiramente mais longo. Os meses que registraram maior número de ocorrências em todo o período foram setembro e outubro.

Palavras-chave: Povoamentos florestais; variáveis meteorológicas; prevenção de incêndios florestais.

\section{INTRODUCTION}

Knowledge and interpretation of meteorological phenomena always raised human curiosity due to weather influence on the most various anthropic activities (SOARES; BATISTA, 2004). In the field of forest protection, for example, meteorological variables play an outstanding role on occurrences of forest 
fires (ZUMBRUNNEN et al., 2011). Elements of climate have great influence of behavior of fire, from ignition to propagation and grade of difficulty during suppression (HEIKKILÄ et al., 2007). Topographic characteristics, ignitable material and meteorological conditions determine severity of the fire and quantity of carbon released in the atmosphere (SIBANDA, 2011; TETTO et al., 2011). According to Heikkilä et al. (2007), climate is related to forest fires in two ways: determining duration and severity of the fire, and since vegetation strongly depends on climatic conditions, determines quantity and quality of the available flammable material. Climate can be seen as being the average between climatic elements variations and their extreme peak deviations. This information is important when looking for a panoramic of what is expected from climate. To organize prevention activity and fight forest fires, and to direct resources in a forest company, data on temperature, rainfall, relative humidity, beginning and ending of the dry season, are necessary. With such information, it is possible to predict precisely the behavior of the fires season in a determined region.

Humidity contained in the fuel material is one of the contributing factors to biomass combustion, being variation of humidity influenced by the seasons of the year (HEIKKILÄ et al., 2007). Vegetation and fuel material absorb humidity during the rainy period, and loose it during the dry season. Thus, continuous monitoring and precise analysis of the meteorological variables are necessary, to reach a more efficient and economic management of prevention activities, control and fight of forest fires (SOARES; BATISTA, 2007).

To minimize population losses in stands due to forest fires, it is important to develop and activate an efficient apparatus aiming to detect and fight fires. Classification of danger level in fires and prediction of potential fires behavior are directly related to climate variations and are indicators normally used to define the level of preparation required and quantity of resources to allocate (FERNANDES; RIGOLOT, 2007).

Neumann (1996) highlights that one of the serious problems that technicians of forest companies are still facing today is related to prevention, pre-suppression and suppression measures which must be taken against forest fires. Process starts from convincing the owner, particularly the one who thinks that this happens only with other companies, to final installation of physical and financial protection structures.

In the period from 2010 to 2012, stands of Pinus sp and Eucalyptus sp, located in northern Mozambique, particularly in the Niassa province, have seen cases of forest fires. Only the company Chikweti Forest of Niassa lost 3500 hectares of young stands in the Niassa province district where it operates, and the district of Lichinga was the one with the greatest losses. Since the area has a very long dry period (from May to November), climate is suspect to be one of the important factors in the occurrences of forest fires. Thus, this work aimed to determinate the influence of meteorological variables in forest fires occurrences in forest stands of Niassa province, district of Lichinga.

\section{MATERIAL AND METHODS}

\section{Characterization of the study area}

The study was conducted in the district of Lichinga, province of Niassa, located in northern Mozambique, coordinates $13^{\circ} 23^{\prime} 48^{\prime \prime} \mathrm{S}$ e $35^{\circ} 13^{\prime} 43^{\prime \prime}$ E. Altitude of the region varies from 1000 to 1300 m(Figure 1). The area is part of an extensive cultivation of Pinus sp and Eucalyptus sp that began to be established in 2005. Most of plantations were established in marginal areas, where local communities practiced subsistence agriculture that was abandoned due to the low productivity level. Composition of the predominant original forest of the region, before plantation of the projects is known as "miombo" and can be still fund in adjacent areas. According to Frost (1966), miombo is the most predominant forest formation in the African continent, covering approximatively 2.7 million of $\mathrm{km}^{2}$, located in the tropical region, usually occurring on poor and badly drained soils. Miombo differs from other forest formations and from African savannas for having predominance of three Fabaceae species, subfamily Caesalpinoideae, particularly of the genus Brachystegia, Julbernardia and Isoberlinia (FROST, 1996; RIBEIRO et al., 2008).

According to Köppen classification, climate of the region is humid temperate (Cwb), with two well disinguished seasons (temperate and rainy summers and dry cold winters). The region presents average annual rainfall varying between 1000 and $1500 \mathrm{~mm}$ while the average annual temperature is between 20 and $23^{\circ} \mathrm{C}$ (MINISTÉRIO DA ADMINISTRAÇÃO ESTATAL (MAE), 2005; SOARES; BATISTA, 2004). 


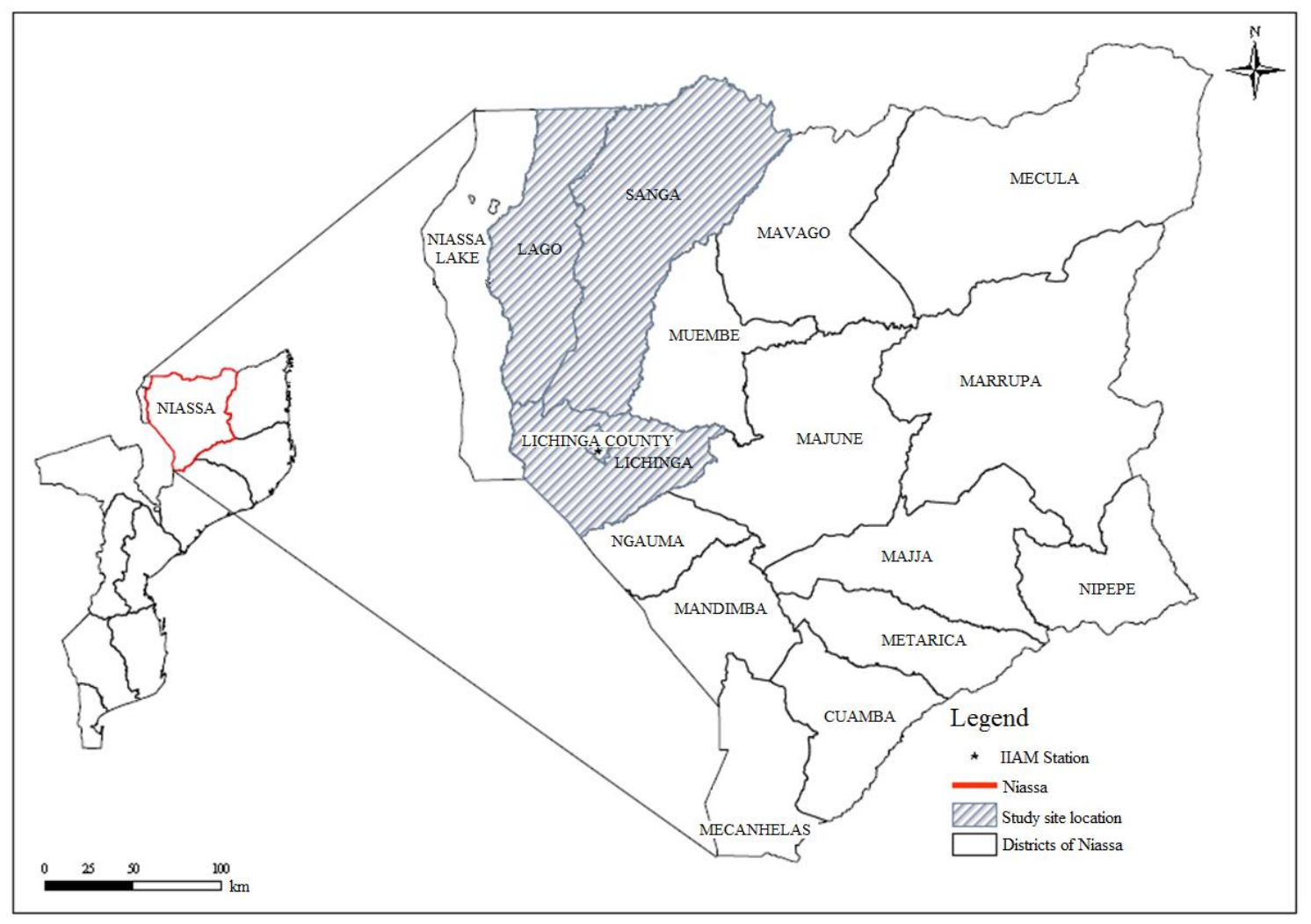

Figure 1. Study site location.

Figura 1. Localização da área de estudo.

\section{Data collection}

Data on forest fire occurrences of Lichinga, Lago and Sanga districts, regarding years from 2010 to 2012, were provided by the Center for Monitoring and Control of Forest Fires (CCMIF) of the Chikweti Company of Niassa. This center was created in 2010 with the intent of monitoring forest fires occurrences, by radio, during all the steps of firefighting (ignition, detection, displacement of firefighters, fighting, until the moment of damage evaluation after the fire), acting 24 hours a day all week long. All data are recorded, including additional data on evaluation after fire.

Daily meteorological data of max and min temperature, rainfall and relative humidity, referring to the period from January 2009 to December 2012, were recorded at 13 p.m., by the meteorological station of the Agronomic Investigation Institute of Mozambique (IIAM), district of Lichinga (Figure 1), and were lately provided to support this research.

\section{Analysis of data}

To determine the influence of meteorological variables and seasons of the year on forest fires occurrences, data were treated considering the two main seasons of the year (summer and winter), which determine behavior of the meteorological variables, directly influencing availability and disposition of forest fuels, and consequently fire occurrence.

Normality test - not parametric- was applied to evaluate monthly homogeneity of data, in accordance to the World Meteorological Organization (WMO), Technical Note no 81 (MINUZZI et al., 2007a; MINUZZI, 2010). The Bartlett's test was used in this work, starting from the null hypothesis that meteorological data follow a normal distribution. According to Costa Neto (2007), normality test is indispensable, because it checks the null hypothesis that all population means are equal, in other words that variance of the population is the same, ensuring that the variables of interest have normal distribution in the whole population. 
Grouping of the meteorological variables was made in function of the months of the year considering the studied period. Two methods were chosen to test tendencies of the meteorological variables: analysis of regression test and comparison of means test, with the test of Tukey to compare the monthly means of the meteorological variables. ASSISTAT 7.7 software was used for the analysis of variance (ANOVA) and to test differences between monthly and annual means of the climatic variables.

Methodology of the analysis of regression was based on what proposed by Minuzzi et al. (2007a and 2010) and Minuzzi (2010), which consists in indicating climatic alterations by significance of the angular coefficient of the considered variables. The test is conducted determining the confidence intervals of the coefficient, and if this interval does not include zero, tendency is significant.

Dates of Beginning of the Rainy Period (IPC) and End of the Rainy Period (FPC) were determined in accordance to the criteria proposed by Sansigolo (1989) and Minuzzi et al. (2006). Rainy period begins in the first day after a specific date when rainfall reaches the minimum quantity of $20 \mathrm{~mm}$, given in one or two days, and during the next 30 days there is at least one rainy day each 10 days. A rainy day is considered when rainfall reaches at least $1.0 \mathrm{~mm}$, because generally less than this quantity will not let water infiltrate into soil (MINUZZI et al., 2007b). FPC will be the first day of the dry period, during at least 15 days. IPC indicates the Final of the Dry Period (FPS) and FPC indicates the Beginning of the Dry Period (IPS). As support in determining IPC and FPC, standard distribution of temperature and relative humidity variables related to rainfall were considered. This was because in the study area, during the rainy season (summer), the highest temperatures of the year are registered, observing a decreasing tendency when winter gets closer, with its dry and cold weather (INSTITUTO NACIONAL DO DESENVOLVIMENTO DA EDUCAÇÃO (INDE, 2009)). According to Soares and Batista (2004), maximum peaks of relative humidity occur also in the rainy season.

Determination of IPC and FPC is an important tool to predict behavior of forest fires, because late beginnings of IPC and early finals of FPC indicate prolonged dry seasons during the year, and consequently increased index of fire danger, favoring forest fires occurrences.

To understand how climatic variations and seasons of the year influenced fire occurrences during the year, monthly registers of fire occurrences were compared to monthly means of the meteorological variables. This comparison allowed understanding if the hottest and dry months coincided with the biggest number of forest fires. Percentage of number of days of each month with fires occurrences was also analyzed. According to Tetto (2012), this variable allows to identify the normal season of fire danger, since it differentiates months with great number of days with fires from months without fires.

\section{RESULTS AND DISCUSSION}

Results of the Bartlett's test showed that monthly means variances of meteorological variables are homogeneous, thus no transformation of data is needed. It was not possible to determine homogeneity of means for months from May to October, because in at least one of the considered months there was no rainfall at all, resulting in a monthly variance equal to zero.

In table 1 are represented monthly statistics of the grouped variables for the three studied years (2010 to 2012), and it is observable that temperature suffered the lowest coefficient of variation, oscillating from 4.77 to 9.77 , while rainfall was the variable with the greatest coefficients of monthly variation with an interval varying from 101.81 to 970.43 . From May to November there were almost no registered rainfalls, with minimum rainfall values indicating that, even in commonly rainy months, there is at least one day with no rainfall occurrence. February was rainfall peak month $(11.57 \mathrm{~mm}$ of average daily rainfall).

Coefficients of rainfall variation tend to be bigger in driest months, diverging from values registered by Rodrígues (2012), who analyzed rainfall behavior data of 11 meteorological stations in Pinar del Rio (Cuba), finding greatest variations in the rainy season. This behavior during winter is probably due to Pinar del Rio showing great differences between rainfalls in the rainy season, in different days in the same month, being the opposite in the dry season. It is important to observe that in Pinar del Rio the minimum observed rainfall in dry months is around $9 \mathrm{~mm}$ and minimum and maximum values are closer each other in months with less rainfalls. 
Table 1. Monthly statistics of the meteorological variables in three studied years.

Tabela 1. Estatísticas mensais das variáveis meteorológicas nos três anos de estudo.

\begin{tabular}{|c|c|c|c|c|c|c|c|c|c|c|c|c|}
\hline \multirow{2}{*}{ Months } & \multicolumn{4}{|c|}{ Temperature $\left({ }^{\circ} \mathrm{C}\right)$} & \multicolumn{4}{|c|}{ Rainfall (mm) } & \multicolumn{4}{|c|}{ Relative humidity (\%) } \\
\hline & Max & Min & Ave & CV\% & Max & Min & Ave & CV\% & Max & Min & Ave & CV\% \\
\hline Jan & 22.25 & 17.15 & 19.71 & 4.77 & 63.90 & 0 & 8.06 & 136.67 & 100 & 46 & 80.32 & 13.71 \\
\hline Feb & 22.95 & 16.35 & 19.68 & 6.96 & 47.00 & 0 & 11.57 & 101.81 & 100 & 54 & 79.16 & 12.62 \\
\hline Mar & 21.80 & 15.80 & 19.42 & 6.33 & 45.80 & 0 & 6.97 & 136.79 & 100 & 50 & 83.25 & 12.23 \\
\hline Apr & 20.70 & 15.00 & 18.43 & 6.78 & 30.90 & 0 & 2.97 & 193.41 & 100 & 52 & 83.18 & 11.88 \\
\hline May & 19.50 & 15.05 & 17.55 & 6.33 & 5.10 & 0 & 0.07 & 797.14 & 100 & 51 & 75.13 & 14.77 \\
\hline Jun & 20.95 & 12.90 & 15.84 & 9.66 & 7.20 & 0 & 0.10 & 788.76 & 96 & 48 & 75.14 & 15.76 \\
\hline Jul & 19.15 & 12.65 & 15.56 & 8.55 & 1.80 & 0 & 0.02 & 883.50 & 98 & 21 & 66.54 & 23.14 \\
\hline Aug & 22.00 & 12.60 & 16.48 & 9.77 & 5.20 & 0 & 0.12 & 527.84 & 98 & 38 & 68.26 & 19.07 \\
\hline Sep & 20.25 & 15.55 & 17.88 & 5.15 & 0.65 & 0 & 0.01 & 710.53 & 85 & 26 & 59.43 & 17.78 \\
\hline Oct & 23.70 & 15.40 & 20.93 & 7.07 & 4.60 & 0 & 0.05 & 970.43 & 80 & 32 & 53.50 & 18.88 \\
\hline Nov & 24.60 & 16.30 & 21.87 & 7.13 & 28.40 & 0 & 1.61 & 303.72 & 96 & 41 & 60.88 & 18.89 \\
\hline Dec & 23.05 & 16.65 & 20.25 & 6.86 & 59.50 & 0 & 9.30 & 126.00 & 100 & 54 & 78.08 & 14.32 \\
\hline Average & 21.74 & 15.12 & 18.63 & 7.11 & 25.00 & 0 & 3.40 & 473.05 & 96.08 & 42.75 & 71.91 & 16.09 \\
\hline
\end{tabular}

Statistics were made grouping monthly values of the three studied years (2010 to 2012); Max= maximum,

Min=minimum, $\mathrm{CV} \%=$ coefficient of variation in percentage.

In table 2, results of the test of significance on coefficients of the meteorological variables are reported $\left(b_{1}\right)$. It is possible to observe that although rainfall has presented very high monthly coefficients of variation, this was the only variable that did not present monthly differences in the three studied years, both by test of regression and test of Tuckey (Table 3). Temperature presented the greatest monthly variation between years by the test on coefficient of regression, being detected significant differences in the months of March, May, June, July, August, September, December $\left(\alpha=0.00^{* *}\right)$ and October $(\alpha=$ $0.03 *$ ), while the test of Tuckey only detected significant differences in the months of February, August and December. Opposite to temperature, relative humidity presented smaller monthly variation between the studied years by the test on coefficient of regression, finding significant differences only in the months of May $(\alpha=0.01 * *)$ and July $(\alpha=0.03 *)$, while the test of Tuckey detected significant differences in the months of January, July, August and September.

Table 2. Values of coefficients $\left(\beta_{1}\right)$ for the climatic variables.

Tabela 2. Valores dos coeficientes $\left(\beta_{1}\right)$ para as variáveis climáticas.

\begin{tabular}{|c|c|c|c|c|c|c|}
\hline \multirow{2}{*}{ Variables } & \multicolumn{6}{|c|}{ Calculated p values } \\
\hline & Jan & Feb & Mar & Apr & May & Jun \\
\hline \multirow{2}{*}{ Temperature $\left({ }^{\circ} \mathrm{C}\right)$} & $(1.41)$ & $(3.62)$ & $(7.87)$ & $(-8.50)$ & $(-8.93)$ & $(5.14)$ \\
\hline & $0.64^{\mathrm{ns}}$ & $0.07^{\mathrm{ns}}$ & $0.00 * *$ & $0.00 * *$ & $0.00 * *$ & $0.00 * *$ \\
\hline \multirow{2}{*}{ Rainfall (mm) } & $(-0.28)$ & $(0.16)$ & $(-0.002)$ & $(-0.42)$ & $(-4.71)$ & $(4.91)$ \\
\hline & $0.26^{\mathrm{ns}}$ & $0.48^{\mathrm{ns}}$ & $0.99^{\mathrm{ns}}$ & $0.39^{\mathrm{ns}}$ & $0.37^{\mathrm{ns}}$ & $0.17^{\mathrm{ns}}$ \\
\hline \multirow{2}{*}{ Relative humidity (\%) } & $(-0.07)$ & $(-0.27)$ & $(-0.42)$ & $(-0.35)$ & $(0.65)$ & $(0.05)$ \\
\hline & $0.78^{\text {ns }}$ & $0.33^{\mathrm{ns}}$ & $0.13^{\mathrm{ns}}$ & $0.22^{\mathrm{ns}}$ & $0.01 * *$ & $0.82^{\text {ns }}$ \\
\hline Variables & Jul & Aug & Sep & Oct & Nov & Dec \\
\hline \multirow{2}{*}{ Temperature $\left({ }^{\circ} \mathrm{C}\right)$} & $(7.63)$ & (13.07) & $(8.98)$ & $(4.02)$ & $(2.73)$ & $(9.37)$ \\
\hline & $0.00 * *$ & $0.00 * *$ & $0.00 * *$ & $0.03^{*}$ & $0.12^{\text {ns }}$ & $0.00 * *$ \\
\hline \multirow{2}{*}{ Rainfall (mm) } & $(-6.61)$ & $(-8.21)$ & $(-6.52)$ & $(-5.71)$ & $(0.57)$ & $(-0.26)$ \\
\hline & $0.66^{\text {ns }}$ & $0.07^{\text {ns }}$ & $0.86^{\text {ns }}$ & $0.33^{\text {ns }}$ & $0.32^{\text {ns }}$ & $0.28^{\text {ns }}$ \\
\hline \multirow{2}{*}{ Relative humidity (\%) } & $(-0.39)$ & $(0.34)$ & $(0.09)$ & $(0.21)$ & (0.39) & $(-0.02)$ \\
\hline & $0.03^{*}$ & $0.11^{\mathrm{ns}}$ & $0.72^{\mathrm{ns}}$ & $0.45^{\mathrm{ns}}$ & $0.11^{\mathrm{ns}}$ & $0.94^{\mathrm{ns}}$ \\
\hline
\end{tabular}

ns $=$ not significant, $*=$ significant at $5 \%$ level and $* *=$ significant at $1 \%$ level. Values of coefficients are between brackets.

In years where differences between means of temperature were detected, both by the test of regression and by the test of comparison of the means (Table 3), it is observed that temperature tends to increase in the last years (2011 and 2012), except in May, where an opposite tendency was observed. Since the study covers a very short period of time, no inference can be done, because according to Johnston et al. (2006), changes in variables like temperature and rainfall occur in quite long periods of time, creating subtle and complex effects in many ecosystems. 
Considering behavior of the mean values of meteorological variables within years, it was observed that the test of Tuckey (Table 3) grouped all meteorological variables in two big groups. There was a season with the greatest rainfall (December to March), with high monthly mean values of temperature and relative humidity; and another season with almost no registered rainfall, and monthly mean values of temperature and rainfall tending to be lower (April to November). This monthly grouping pattern of variables suggests the definition of the climate in this region which, according to Köppen classification, is humid temperate $(\mathrm{Cwb})$, with two well distinct seasons: temperate and rainy summers and cold rainy winters (INDE, 2009; MAE, 2005).

Table 3. Results of Tukey test for monthly and annual comparison of means.

Tabela 3. Resultados do teste de Tukey para comparação mensal e anual de médias.

\begin{tabular}{lccccccc}
\hline \multirow{2}{*}{ Months } & \multicolumn{3}{c}{ Temperature $\left({ }^{\mathbf{0}} \mathbf{C}\right)$} & \multicolumn{2}{c}{ Rainfall (mm) } & \multicolumn{2}{c}{ Relative humidity (\%) } \\
\cline { 2 - 7 } & $\mathbf{2 0 1 0}$ & $\mathbf{2 0 1 1}$ & $\mathbf{2 0 1 2}$ & $\mathbf{2 0 1 0} \mathbf{2 0 1 2}$ & $\mathbf{2 0 1 0}$ & $\mathbf{2 0 1 1}$ & $\mathbf{2 0 1 2}$ \\
\hline Jan & $19.83^{\text {abca }}$ & $19.37^{\text {bcda }}$ & $19.93^{\text {bcda }}$ & $8.12^{\text {ab }}$ & $84.23^{\text {aa }}$ & $72.36^{\text {abcb }}$ & $84.57^{\text {aa }}$ \\
Feb & $19.93^{\text {abca }}$ & $18.33^{\text {cdeb }}$ & $20.70^{\text {aba }}$ & $11.43^{\text {a }}$ & $78.30^{\text {aa }}$ & $80.33^{\text {aa }}$ & $77.87^{\text {abca }}$ \\
Mar & $19.14^{\text {bcda }}$ & $19.03^{\text {bcda }}$ & $20.08^{\text {bca }}$ & $6.65^{\text {bca }}$ & $84.59^{\text {aa }}$ & $84.45^{\text {aa }}$ & $81.62^{\text {aba }}$ \\
Apr & $19.17^{\text {bcda }}$ & $18.20^{\text {dea }}$ & $18.07^{\text {dea }}$ & $2.98^{\text {cd }}$ & $83.60^{\text {aa }}$ & $83.57^{\text {aa }}$ & $82.53^{\text {aba }}$ \\
May & $18.13^{\text {cda }}$ & $17.50^{\text {defa }}$ & $16.93^{\text {efa }}$ & $0.07^{\text {d }}$ & $72.70^{\text {abca }}$ & $72.83^{\text {aba }}$ & $80.30^{\text {aba }}$ \\
Jul & $15.13^{\text {ea }}$ & $16.07^{\text {aa }}$ & $16.43^{\text {efa }}$ & $0.10^{\text {d }}$ & $74.57^{\text {aba }}$ & $75.73^{\text {aba }}$ & $74.83^{\text {abcda }}$ \\
Jul & $14.87^{\text {ea }}$ & $15.83^{\text {fa }}$ & $15.97^{\text {fa }}$ & $0.02^{\text {d }}$ & $74.80^{\text {aba }}$ & $59.40^{\text {cdb }}$ & $65.17^{\text {cdeb }}$ \\
Aug & $15.00^{\text {eb }}$ & $16.47^{\text {efa }}$ & $17.80^{\text {efa }}$ & $0.10^{\text {d }}$ & $64.67^{\text {bcdab }}$ & $58.83^{\text {db }}$ & $72.13^{\text {abcda }}$ \\
Sep & $17.83^{\text {da }}$ & $17.57^{\text {defa }}$ & $18.17^{\text {cdea }}$ & $0.01^{\text {d }}$ & $60.27^{\text {cdb }}$ & $58.27^{\text {db }}$ & $69.73^{\text {bcda }}$ \\
Oct & $20.77^{\text {aba }}$ & $20.90^{\text {aba }}$ & $21.00^{\text {aba }}$ & $0.04^{\text {d }}$ & $53.17^{\text {da }}$ & $53.37^{\text {da }}$ & $54.20{ }^{\text {ea }}$ \\
Nov & $21.50^{\text {aa }}$ & $21.87^{\text {aa }}$ & $22.23^{\text {aa }}$ & $2.62^{\text {d }}$ & $58.17^{\text {da }}$ & $65.73^{\text {bcda }}$ & $63.53^{\text {dea }}$ \\
Dec & $19.20^{\text {bcdb }}$ & $20.27^{\text {abcab }}$ & $21.33^{\text {aba }}$ & $9.20^{\text {ab }}$ & $78.07^{\text {aa }}$ & $18.20^{\text {aba }}$ & $77.07^{\text {abca }}$ \\
\hline
\end{tabular}

Lower case letters in columns and upper case letters in lines. Means with the same letter are not significantly different by the test of Tuckey at $5 \%$ level.

Monthly grouping of meteorological variables detected by the test of Tuckey test, especially for the rainfall variable, coincides with IPC and FPC (Table 4), considering that the rainy period goes from middle December to final of Abril.

Table 4. The beginning of the rainy and dry season (IPC and IPS), the end of the rainy and dry season (FPC and FPS) in the three years studied.

Tabela 4. Início do período chuvoso e seco (IPC e IPS), final do período chuvoso e seco (FPC e FPS) nos três anos estudados.

\begin{tabular}{l|c|c|c|c}
\hline \multirow{2}{*}{ Years } & \multicolumn{2}{|c|}{ Rainy period } & \multicolumn{2}{c}{ Dry period } \\
\cline { 2 - 5 } & IPC & FPC & IPS & FPS \\
\hline 2010 & $08 / \mathrm{Nov} / 2009$ & $01 / \mathrm{May} / 2010$ & $01 / \mathrm{May} / 2010$ & $08 / \mathrm{Dec} / 2010$ \\
2011 & $08 / \mathrm{Dec} / 2010$ & 11/Apr2011 & $11 / \mathrm{Apr} / 2011$ & $10 / \mathrm{Dec} / 2011$ \\
2012 & $10 / \mathrm{Dec} / 2011$ & 17/Apr/2012 & $17 / \mathrm{Apr} / 2012$ & $26 / \mathrm{Nov} / 2012$ \\
\hline
\end{tabular}

When data of fires occurrences distribution during the months of the year were overlapped to the studied meteorological variables (Figure 2), it was determined that in 2010 the first forest fires occurrences were observed in June, a little later than the first occurrences in 2011 and 2012. The slightly late beginning of dry season in 2010 (01/May/2010) is probably one of the factors determining of the late occurrence of the first fires in that year. According to Machado et al. (1996), early beginnings of IPC indicate a longer PC duration and consequently a delay of PS, determining a less severe and long PC. The International Council for Science (ICSU, 2008) reported that rainfall variations in short, medium and long time scale is one of the main problems influencing decision making at all levels. Floods, droughts and other extreme phenomena related to rainfall variations are common in many African countries, causing severe damages to agriculture, livestock, forest life, tourism, health, water resources and many other important sectors of society. 
Zucule (2003), in his work titled "quantification of burnings in Mozambique" using satellite images, observed that in the entire territory fires would start in the first week of July and ended in the last week of October. This determination is not in accordance with the results found in this work, because probably the main cause that detemines forest fires occurrences in the studied area, is related to human intervention. Besides that, behavior due to arsionists does not follow distribution patterns of the meteorolgical variables. It is also worth to highlight that observations from satelite images may differ from from observations in field, since satelites normally use systems of sensors detecting heat emission from objects on the earth surface (radiometric resolution), and they are not related only to forest fires occurrences (BOSCHETTI et al., 2003; CENTENO, 2009). Besides, due to the low spectral and spatial resolution of satelites, they are of great use when monitoring is made in reginal and continental scales (BOSCHETTI et al., 2003), and not in punctual scale like in the case of this study.

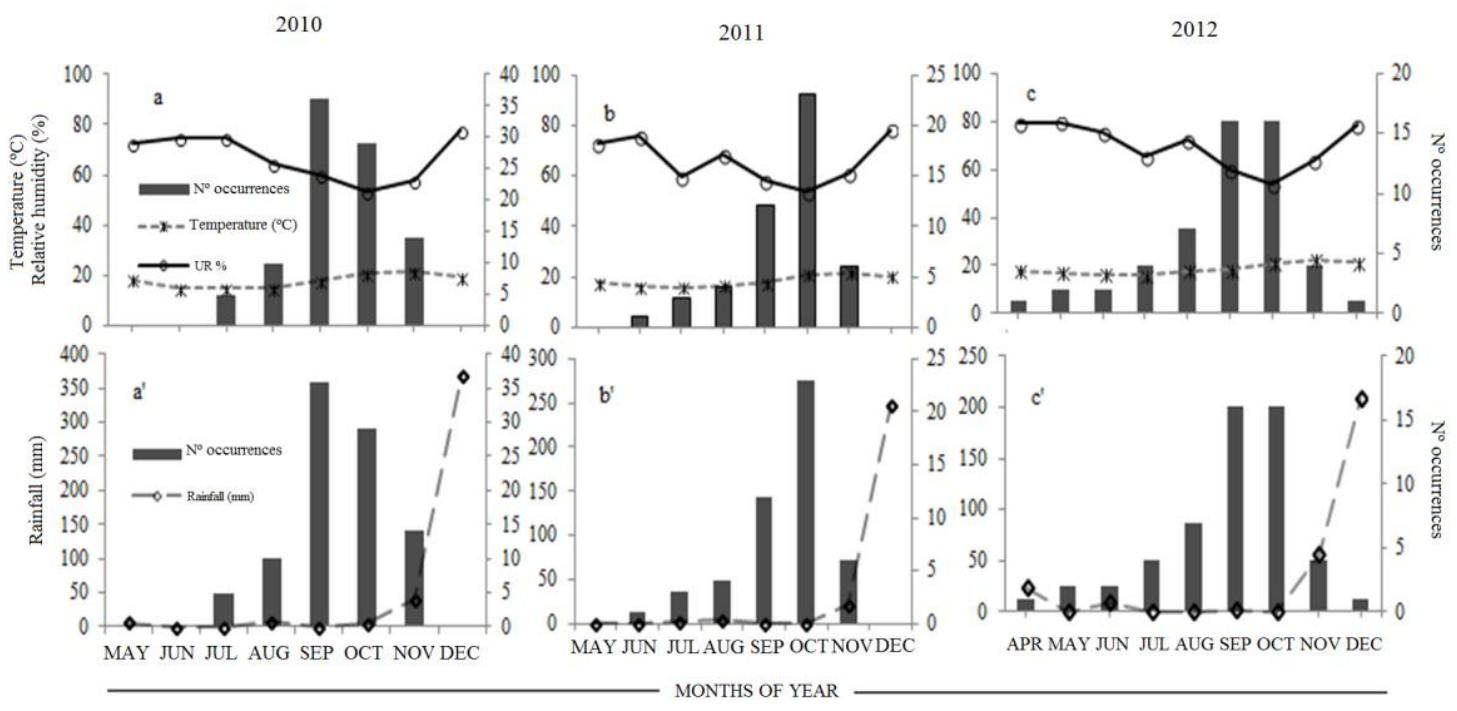

Figure 2. Monthly distribution of forest fires occurrences as a function of the meteorological variables.

Figura 2. Distribuição mensal das ocorrências dos incêndios florestais em função das variáveis meteorológicas.

In all years occurrences tend to increase starting from August and to reach their peaks in September and October (Figure 2 and Table 4). Tetto (2012) also observed the same tendency, even though occurrences in his work spread over a relatively longer period (February to December), with August and September presenting the bigger number of occurrences.

Table 4. Percentage of days of the month with fire occurrences.

Tabela 4. Porcentagem de dias dos meses com ocorrência dos incêndios.

\begin{tabular}{lccccccccc}
\hline \multirow{2}{*}{ Months } & \multicolumn{9}{c}{ Years } \\
\cline { 2 - 10 } & \multicolumn{2}{c}{$\mathbf{2 0 1 0}$} & \multicolumn{9}{c}{$\mathbf{2 0 1 1}$} & \multicolumn{2}{c}{$\mathbf{2 0 1 2}$} \\
\hline ypr & 0.00 & 0.00 & 0.00 & 0.00 & 0.00 & 0.00 & 1.00 & 1.00 & 3.33 \\
May & 0.00 & 0.00 & 0.00 & 0.00 & 0.00 & 0.00 & 2.00 & 2.00 & 6.45 \\
Jun & 0.00 & 0.00 & 0.00 & 1.00 & 1.00 & 3.33 & 2.00 & 1.00 & 3.33 \\
Jul & 5.00 & 5.00 & 16.13 & 3.00 & 3.00 & 10.00 & 4.00 & 4.00 & 12.90 \\
Aug & 10.00 & 8.00 & 25.81 & 4.00 & 4.00 & 12.00 & 7.00 & 5.00 & 16.13 \\
Sep & 36.00 & 25.00 & 83.33 & 12.00 & 10.00 & 33.33 & 16.00 & 9.00 & 30.00 \\
Oct & 29.00 & 22.00 & 73.33 & 23.00 & 15.00 & 51.72 & 16.00 & 11.00 & 35.48 \\
Nov & 14.00 & 10.00 & 46.67 & 6.00 & 6.00 & 20.00 & 4.00 & 4.00 & 13.33 \\
Dec & 0.00 & 0.00 & 0.00 & 0.00 & 0.00 & 3.22 & 1.00 & 1.00 & 3.23 \\
\hline Mean & 10.44 & 7.78 & 27.25 & 5.44 & 4.33 & 14.84 & 5.89 & 4.22 & 13.80 \\
\hline
\end{tabular}

$\mathrm{n}^{\mathrm{o}} \mathrm{oc}=$ number of occurrences; $\mathrm{n}^{\mathrm{o}}$ days $=$ number of days with occurrences; $\%$ days = percentage of days in the month with occurrences.

FLORESTA, Curitiba, PR, v. 45, n. 3, p. 577 - 586, jul. / set. 2015.

Mbanze, A. A. et al.

ISSN eletrônico 1982-4688 / ISSN impresso 0015-3826 
Observing monthly distribution of the meteorological variables, in months where there were fires, it possible to verify that temperature values tend to be high while relative humidity values were low, contributing to easier ignitions and following propagation of forest fires. Chidumayo et al. (1996) commented that, in regions where miombo savannas are predominant, most part and the most severe forest fires occurred at the end of the dry season due to availability of extremely dry biomass in great quantities.

The Ministry for Coordination and Environmental Action (MICOA, 2007) determined the occurrence of 503, 900, 2900 and 6000 fires associated to different causes in the months of June, July, August and September of 2006 in the entire province of Niassa. Thus, data on fires occurrences are similar to data of this work, at least in terms of tendencies. It is important to highlight that this work is referred to fire occurrences in forest stands, and their main cause is associated to arsonists, while data of MICOA (2007) are generic and the main cause of fires is related to itinerant agriculture.

\section{CONCLUSION}

- Registers of average daily rainfall in months from May to November that varied from 0.07 to 2.62 $\mathrm{mm}$ in the three studied year indicate a long dry period, which contributed to the high number of fires in the forest stands.

- Both tests, comparison of means and analysis of regression, showed that monthly values of temperature and relative humidity had significant variations in some months of the three studied years. Temperature showed greater monthly variation by the test of regression while relative humidity showed greatest monthly variation by the test of comparison of means. It is important to highlight that monthly variation of temperature has less influence if compared to variations in periods of the year (periods of drought).

- Rainfall did not present any significant variation in both tests. These variations probably had influence on monthly and yearly distribution standards of fire occurrences.

- The slightly late final of the rainy season probably contributed to a late beginning in fires occurrences in 2010, although this was the year with higher number of occurrences.

- In the months of September and October, which were the last months of dry season, were the ones that registered the greater number of fire occurrences in all the studied years.

\section{REFERENCES}

BOSCHETTI, L.; BRIVIO, P.; GREGOIRE, J. The use of meteosat and GMS imaginary to detect burned areas in the tropical environments. Remote Sensing of Environment, v. 85, p. 78 - 91. 2003.

CENTENO, J. A. S. Sensoriamento remoto e processos de imagens digitais. Curitiba: Universidade Federal do Paraná, 2009. 209 p.

CHIDUMAYO, E.; GAMBIZA, J.; GRUNDY I. Managing miombo woodlands. In: CAMPBELL, B. The miombo in transition: woodland and welfare in Africa. Bogor, Indonesia. Center for International Forestry Research (CIFOR), 1996. p. 175 - 193.

COSTA NETO, P. L. O. Estatística. 2. ed. São Paulo, Brasil., 2007. 266 p.

FERNANDES, P.; RIGOLOT, E. The fire ecology and management of maritime pine (Pinus pinaster Ait.). Forest Ecology and Management, v. 241, p. 1 - 13, 2007.

FROST, P. The ecology of miombo woodlands. In: CAMPBELL, B. The miombo in transition: woodland and welfare in Africa. Center for International Forestry Research (CIFOR): Bogor, Indonesia, 1996. p. 11 - 57.

HEIKKILÄ, T. V.; GRÖNQVIST, R.; JURVÉLIUS, M. Wildland fire management: handbook for trainers. Helsinki, 2007. 248 p.

INSTITUTO NACIONAL DO DESENVOLVIMENTO DA EDUCAÇÃO (INDE). Atlas de Moçambique. Maputo, Moçambique, 2009. 81 p. 
INTERNATIONAL COUNCIL FOR SCIENCE (ICSU).Global environmental change: including climate change and adaptation in sub-saharan Africa. Seychelles, March, 2008.

JOHNSTON, M.; WILLIAMSON, T.; PRICE, D.; SPITTLEHOUSE, D.; WILLISTEAD, A.; GRAY, P.; ASKEW, S.; WEBBER, S. Impacts of climate change in Canada: research integration program. BIOCAP, Canada, 2006.

MACHADO, M. A.; SEDIYAMA, G. C.; COSTA, J. M. N. da; COSTA, M. H. Duração da estação chuvosa em função das datas de início do período chuvoso para o estado de Minas Gerais. Revista Brasileira de Agrometeorologia, v. 4, n. 2, p. 73 - 79, 1996.

MINISTÉRIO DA ADMINISTRAÇÃO ESTATAL (MAE). República de Moçambique. Perfil do distrito de Lichinga. Província de Niassa: MAE, 2005. 54 p.

MINISTÉRIO PARA A COORDENAÇÃO E AÇÃO AMBIENTAL (MICOA). República de Moçambique. Plano de ação para prevenção e controle às queimadas descontroladas 2008 - 2018. 2007. $46 \mathrm{p}$.

MINUZZI, R. B. Tendências na variabilidade climática de Santa Catarina, Brasil. Revista Brasileira de Engenharia Agrícola e Ambiental (Agriambi), Campina Grande, v. 14, n. 12, p. 1288 - 1293, 2010.

MINUZZI, R. B.; CARAMORI, P. H.; BORROZINO, E. Tendências na variabilidade climática sazonal e anual das temperaturas máxima e mínima do ar no estado do Paraná. Bragantia, Campinas, v. 70, n. 2, p. $471-479,2010$.

MINUZZI, R. B.; SEDIYAMA, G. C.; BARBOSA, E. M.; JÚNIOR, J. C. F. Climatologia do comportamento chuvoso da região sudeste do Brasil. Revista Brasileira de Meteorologia, v. 22, n. 3, p. $338-344,2007 b$.

MINUZZI, R. B.; SEDIYAMA, G. C.; JÚNIOR, J. C. F.; CATALUNHA, M. J. Estudo climático do comportamento do período chuvoso no estado de Minas Gerais. Revista Ceres, v. 53, n. 306, p. 266 $275,2006$.

MINUZZI, R. B.; VINELLO, R. L.; SEDIYAMA, G. C. Oscilações climáticas em Minas Gerais. Revista Brasileira de Meteorologia, v. 25, n. 2, p. 227 - 236, 2007 a.

NEUMANN, M. Aspectos técnicos e econômicos da proteção contra incêndios florestais em povoamentos de Pinus spp. 95 f. Dissertação (Mestrado em Engenharia Florestal) - Setor de Ciências Agrárias, Universidade Federal do Paraná, Curitiba, 1996.

RIBEIRO, N. S.; SHUGART, H. H.; SWAP, R. J.; OKIN, G. S. Five-years period of fire regime in the miombo woodlands of Niassa Reserve, Mozambique. International Journal of Wildland Fire, p. 101 133, 2008.

RODRÍGUEZ, M. P. R. Desempeño de los Índices de Nesterov, Fórmula de Monte Alegre y Fórmula de Monte Alegre alterada en la empresa Forestal Macurije Pinar del Río, Cuba. 109 f. Tese (Pósdoutorado em Engenharia Florestal) - Setor de Ciências Agrárias, Universidade Federal do Paraná, Curitiba, 2012.

SANSIGOLO, A. S. Variabilidade interanual de estação chuvosa em São Paulo. Climanálise, Cachoeira Paulista, v. 4, n. 9, p. 40 - 43, 1989.

SIBANDA, C. Modelling forest fire behaviour and carbon emission in the Ludikhola Watershed, Gorkha District, Nepal. 81 f. (Mestrado em Ciências de Geo-informação e Observação da Terra) Faculdade de Ciências de Geo-informação e Observação da Terra, University of Twente, Enschede, The Netherlands, 2011.

SOARES, R. V.; BATISTA, A. C. Meteorologia e climatologia florestal. Curitiba, 2004.195 p.

Incêndios florestais: controle, efeito e usos do fogo. Curitiba, 2007. 250 p.

FLORESTA, Curitiba, PR, v. 45, n. 3, p. 577 - 586, jul. / set. 2015.

Mbanze, A. A. et al.

ISSN eletrônico 1982-4688 / ISSN impresso 0015-3826

585

DOI: $10.5380 /$ rf.v45i3.33742 
TETTO, A. F. Comportamento histórico dos incêndios florestais na Fazenda Monte Alegre no período de 1965 a 2009. 115 f. Tese (Doutorado em Engenharia Florestal) - Setor de Ciências Agrárias, Universidade Federal do Paraná, Curitiba, 2012.

TETTO, A. F.; BATISTA, A. C.; SOARES, R. V. Prevenção e combate aos incêndios florestais. Curitiba: SENAR-PR, 2011. 75 p.

ZUCULE, J. N. Quantificação de queimadas e incêndios em Moçambique usando imagens satélites. 83 f. Monografia (Licenciatura em Engenharia Florestal) - Faculdade de Agronomia e Engenharia Florestal, Universidade Eduardo Mondlane, Maputo, 2003.

ZUMBRUNNEN, T.; PEZZATTI, G. B.; MENÉNDEZ, P.; BUGMANN, H.; BÜRGI, M.; CONEDERA, M. Weather and human impacts on forest fires: 100 years of fire history in two climatic regions of Switzerland. Forest Ecology and Management, v. 261, p. 210 - 219. 2011. 